\title{
インドにおけるサイクロンリスク解析のための確率モデルの基礎研究 A FUNDAMENTAL STUDY ON THE PROBABILISTIC MODEL FOR CYCLONE RISK ANALYSIS IN INDIA
}

\author{
渡 部 弘 之*, 矢 代 晴 実**, 福島 誠一郎*** \\ Hiroyuki WATABE, Harumi YASHIRO and Sei'ichiro FUKUSHIMA
}

\begin{abstract}
Recently, various alternative risk transfer transactions have been issued to diversify the natural catastrophic risk retained by property \& casualty insurers to the financial market instead of traditional reinsurance market. Especially, the catastrophic bond based on the parametric trigger such as the center pressure depth at the cyclone landing is high transparency and objective index for the investors. Gujarat State in western part of India has rarely suffered the heavily losses by intense wind due to cyclone. The study is focused on the development of the cyclone risk model to design risk financing such as risk securitization using parametric trigger. In this study, we statistically analyzed the historical cyclone data to fit the probable distribution function of cyclone parameters. Using these parameters, we stochastically generated a large number of cyclone events to estimate the peak gust wind speed at the assumed portfolio. After applying various types of vulnerability function for buildings to the wind hazard, we obtained the risk curve.
\end{abstract}

Keywords: Risk Finance, Wind Disaster, Risk Curve, Cyclone Simulation, Portfolio リスクファイナンス, 風災, リスクカーブ, サイクロンシミュレーション, ポートフォリオ

\section{1.はじめに}

近年, インドでは人口，資本，労働生産性の增加などを起因として 経済成長を成し遂げ，ここ数年 $8 \%$ 程度の成長率となり，世界平均を 上回る高水準の成長を記録している。今後はさらに，資本蓄積・技術 革新による生産性上界なども見込まれている。こうした成長の中, イ ンドではサイクロン, 地震等の自然災害が頻発しており, 成長の阻害 要因の一つとなっている。特に経済活動の活発な西部地区, 州では地 震およびサイクロンによる被害も発生しており,これらの自然災害り スクへの対応は経済発展を促す上でも極めて重要である。

サイクロンは主にベンガル湾やアラビア海で発生するが, 年間の発 生数 ${ }^{1)}$ は各々約 3 個, 2 個であり, 上陸サイクロン数は, 平均して各々 0.92,0.18 個程度と極めて少ない事象である。特に経済活動の活発な グジャラート周辺の上陸頻度は年間 0.1 個程度となっているが, 財物 の集積度も高く, 過去, 大規模な被害が発生している。

こうした低頻度, 甚大な被害をもたらす事象については, 過去の僅 かな被害データからリスク評価を行うことは難しく, 確率モデルを用 いた確率論的な手法あるいはサイクロンが発生したという条件下で の確定論的なリスク評価手法によらざるを得ない。

ところで,このような事象のリスク低減には，防災のみならずリス クファイナンスによるリスク転嫁が有効である。昨今は通常の保険に
加え, 資本市場に補填を求める証券化 ${ }^{2)}$ 等のリスクファイナンスが 活発化している。こうしたリスクファイナンスの設計と効果の定量把 握等には, 確率論に基づくことが実際的であるため, 確定論的なリス ク評価手法は適さず，確率モデルによる評価を採ることになる。特に 証券化においては, 投資家からの元本没収トリガーとなるパラメトリ ックトリガー注1) の設定のために，確率論的な評価が不可欠となる。 そこで, 本研究では, リスクファイナンスニーズに対応するために, インドのサイクロンリスク証券化に資するサイクロンリスク解析用 の確率モデルの基礎的な検討を行う。

\section{2. サイクロンリスクの評価手法}

サイクロンに伴う被害は強風および降雨によるものがあるが, 過去 の被害事例からは前者が支配的である。そこで本研究では, 前者を扱 うこととする。風災による建物被害の大きさは, 建物構造, 外装材等 の脆弱性により，一般的には最大瞬間風速に依存するものとされてお り,リスク評価にあたっては評価対象物の所在地において予想される 最大瞬間風速データが必要となる。しかし, 当該地における過去の最 大瞬間風速データを得ることは近傍に気象官署がなければならず, 得 られたとしても本検討で対象とする極めて稀に出現するデータを得 ることは困難である。さらには本研究では, 評価対象物のリスクを個
* アジア防災センター 修士 (工学)

** 東京海上日動リスクコンサルティング株) 博士 (工学)

*** 東電設計(侏) 博士 (工学)
Asian Disaster Reduction Center, M. Eng.

The Tokio Marine \& Nichido Risk Consulting Co., Ltd., Dr. Eng.

Tokyo Electric Power Services Co., Ltd., Dr. Eng. 
別に評価するのではなく, 広域に点在した複数の評価対象物をポート フォリオとして扱い，被害の相関を加味して同時に評価する。

したがって, 本検討では, まず, 過去のサイクロンパラメータの統 計量を分析し,これを基に仮想的に生成したサイクロンを用いて複数 の評価対象地点にて最大瞬間風速を推定する。次に, 得られた最大瞬 間風速情報を基に構造物の損傷度を基に設定したバルナラビリティ カーブを適用し, 広域に点在するポートフォリオの被害を推定し, 確 率論的に風災リスク評価を行うこととした。

\section{3. サイクロンパラメータの設定}

最大瞬間風速の推定は，サイクロンの気圧分布をモデル化し，計算 により推定する必要がある。ここでは，サイクロンの襲来頻度，中心 気圧差, 進行速度, 進行角度, 最大旋衡風速半径, 上陸後の中心気圧 減衰率について設定する。

\section{1 統計分析に用いるデータ}

分析に用いたデータはJoint Typhoon Warning Center (JTWC) によ る North Indian Ocean の Best Track データ ${ }^{3)}$ である。統計期間は 1945-2005 年と長期に亘っているが，必要なパラメータが均質的に得 られるのは 1972 年以降であることから，分析対象とするデータ期間 を1972-2005 年の 34 年間とした。

分析対象地域は，インド全域ではなく，サイクロンリスク証券化の ために対象とするグジャラート州周辺地域とし，図 1 に示すようにグ ジャラート州周辺の海岸沿い設定した $620 \mathrm{~km}$ のゲートを通過した過 去のサイクロンを分析対象とする。一般に大半のサイクロンは北上す る際にアラビア海上の北緯 15〜20にて偏向 ${ }^{4)}$ し北東一進むことが知 られており,偏向したサイクロンを設定したゲートで捉えることがで きる。また，対象地域では 10 年間に 1 個程度のサイクロンが上陸す るのみであり, 過去のサイクロンのみを対象としただけではデータ数 の点で不十分である。ここでは評価対象とするデータを, サイクロン の定義に満たない最大風速 $64 \mathrm{knot}(33 \mathrm{~m} / \mathrm{s})$ 末満のトロピカルストー ム（以下，TS）にも広げた。ただし，中心気圧が $1000 \mathrm{hpa}$ を回る 衰弱したものについては分析対象から除外した。

次に，ゲートを通過した TS の経路を図 2 に示す。大半は，ゲート を南西側より北東側に通過するが，一部，東側の大陸側からゲートを 西側に通過する TS も見られる。これらについては勢力も弱く，分析 対象から外すこととした。以上より分析対象となる過去のサイクロン 数（一部 TS を含む）は9 個となった。

なお，最大瞬間風速の推定には，中心気圧および最大旋衡風速半径 $R_{m}$ のパラメータが必要である。しかしながら，中心気圧については JTWC では観測していない。そのため，中心気圧については， Atokinson-Holiday ${ }^{5}$ による(1)式を用いて JTWCにより公表されたサイ クロン中心付近での最大風速値を基に中心気圧を推定した。

$$
V_{\max }=6.7 \cdot\left(P_{n}-P_{c}\right)^{0.644}
$$

ここに, $V_{\text {max }}$ は中心付近での最大風速 $(\mathrm{knot}), P_{c}$ は中心気圧 (hpa), $P_{n}$ は周辺気圧 (hpa) であり, ここでは周辺気圧を 1010hpa ${ }^{6)}$ と設定 した。また， $R_{m}$ も観測データは 2001 年以降しかなく, 勢力の強い サイクロンに対して十分なデータが揃わないことから, 既往の研究デ ータ 7)を用いることとした。表 1 に使用サイクロンデータを示す。

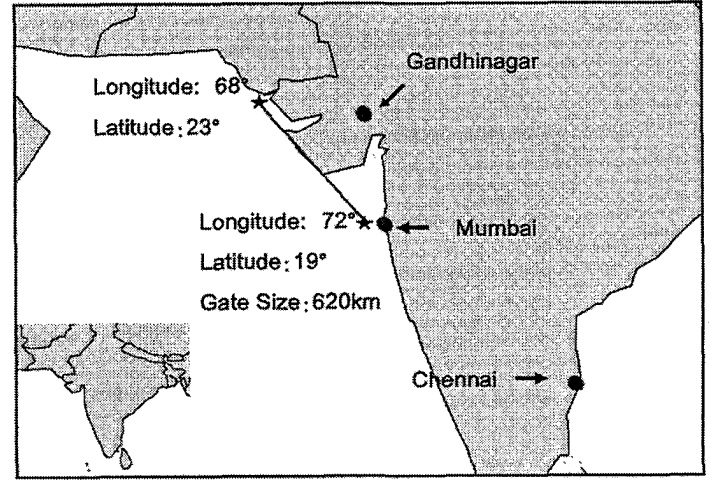

図 1 設定ゲート

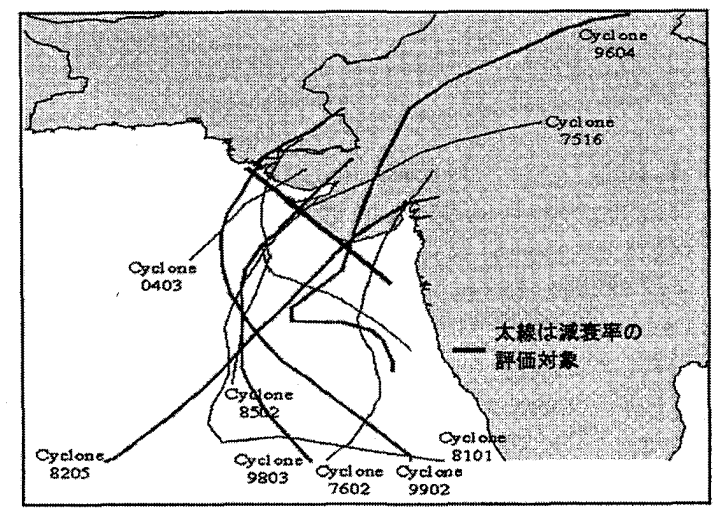

図 2 設定ゲートを通過したサイクロン（1972-2005 年）

表 1 ゲート付近通過時における過去のサイクロンデータ

\begin{tabular}{r|r|r|r|r|r|r|r|r|r}
\hline Year & Month & Day & $\begin{array}{r}\text { Storm } \\
\text { ID }\end{array}$ & $\begin{array}{l}\text { Longitude } \\
\text { (Deg.) }\end{array}$ & $\begin{array}{c}\text { Latitude } \\
\text { (Deg.) }\end{array}$ & $\begin{array}{c}\text { Wax. } \\
\text { Wind Speed } \\
\text { at the Eye } \\
\text { of Cyclone } \\
\text { (knot) }\end{array}$ & $\begin{array}{c}\text { Estimated } \\
\text { Central } \\
\text { Pressure } \\
\text { (hpa) }\end{array}$ & $\begin{array}{c}\text { Transiation } \\
\text { al Speed } \\
(\mathrm{km} / \mathrm{hr} \text { ) }\end{array}$ & \multicolumn{1}{c}{$\begin{array}{c}\text { Angle } \\
\text { (Deg.) }\end{array}$} \\
\hline \hline 1975 & 10 & 22 & 16 & 21.2 & 68.8 & 80 & 963 & 18 & 56 \\
\hline 1976 & 6 & 2 & 2 & 19.6 & 71.4 & 40 & 994 & 13 & 81 \\
\hline 1981 & 11 & 1 & 1 & 21.6 & 69.2 & 45 & 991 & 19 & 51 \\
\hline 1982 & 11 & 8 & 5 & 20.1 & 70.3 & 85 & 958 & 26 & 53 \\
\hline 1985 & 5 & 31 & 2 & 22.8 & 68.4 & 40 & 994 & 9 & 79 \\
\hline 1996 & 6 & 18 & 4 & 20.3 & 70.8 & 65 & 976 & 13 & 83 \\
\hline 1998 & 6 & 9 & 3 & 21.5 & 69.0 & 105 & 938 & 29 & 57 \\
\hline 1999 & 5 & 20 & 2 & 23.1 & 67.9 & 110 & 933 & 11 & 60 \\
\hline 2004 & 10 & 3 & 3 & 22.2 & 67.8 & 35 & 997 & 40 & 40 \\
\hline
\end{tabular}

\section{2 パラメータの統計量}

ダートを通過したサイクロンの頻度について分析を行った。ダート 通過サイクロン数がポアソン過程に従うかを,カイ二乗検定により確 認したところ, 図 3 に示すように有意水準 $5 \%$ でポアソン分布が妥当 であることが確認できた。

次に,リスク評価で必要となる最大瞬間風速を推定するためのパラ メータについての分析を行った。必要なパラメータは, ゲート通過個 数, ゲート付近通過時の中心気圧と周辺気圧との差, 進行速度, ゲー 卜通過角度， $R_{m}$ およびゲート通過後の気圧隇衰率である。

各パラメータに過去のデータに対してフィッティングした累積確 率密度関数を図 4〜6に示す。また，図 7 に示すように確率紙により 正規分布, 対数正規分布, ワイブル分布一の適合性を調べたが，中心 気圧差，進行速度に対しては対数正規分布が，また角度に対しては正 規分布への適合度が高かった。なお, 各パラメータの平均值, 標準偏 差については，確率紙上の切片，傾きより算出した。 


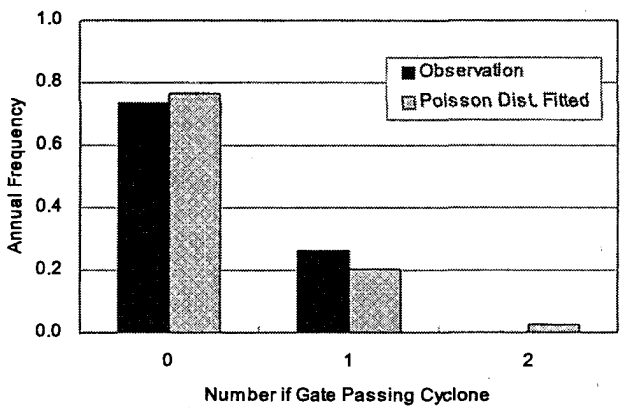

図 3 ゲート通過サイクロンの頻度分布

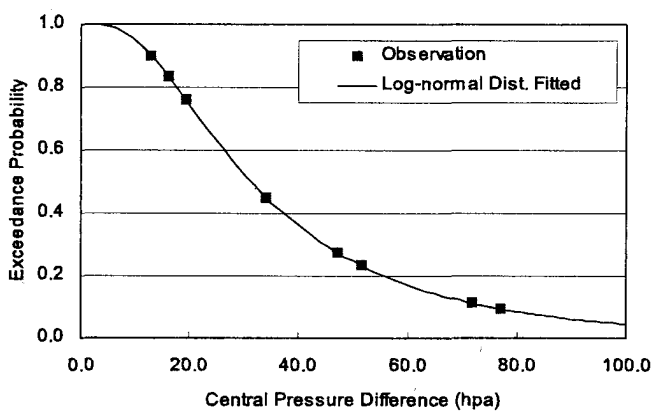

図 4 気圧差の分布

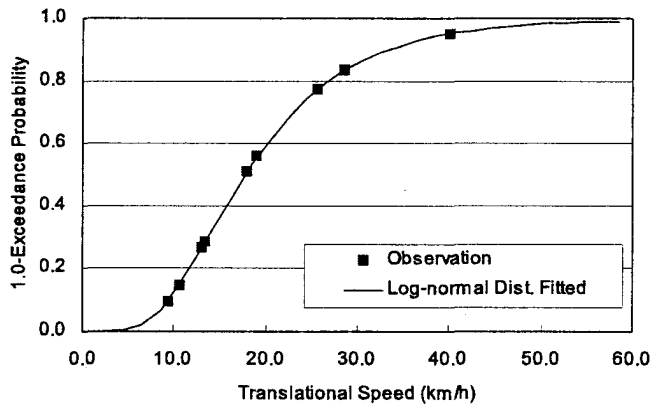

図 5 進行速度の分布

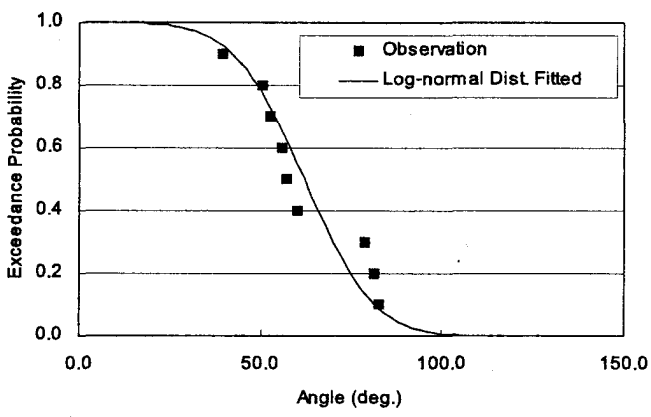

図 6 進行角度（経線に対する角度）
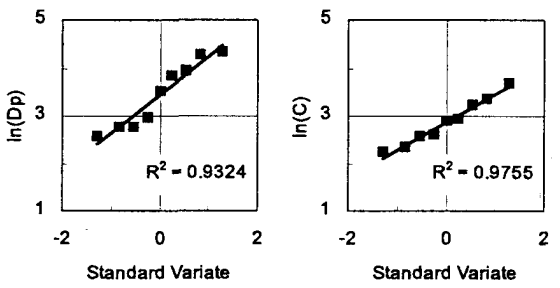

Central Pressure Distance

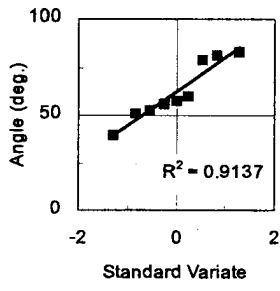

Angle
Translational Speed
パラメータ間の相関関係を図 8 に示す。中心気圧差と他の 2 変数と の間の相関係数は極めて小さい。一方, 進行速度と角度については,

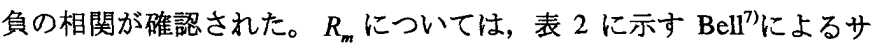
イクロンの中心気圧と $R_{m}$ との関係を用いた。中心気圧が低いサイク ロン程，小さくなる傾向がある。

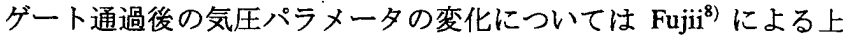
陸後の気圧差変化についての以下の式を用いて評価した。

$$
\Delta p=\Delta p_{0} \cdot \exp \left(-a_{p} \cdot t\right)
$$

ここに， $\Delta p_{0}$ はゲート通過時における中心気圧と周辺気圧との差 (hpa), $\Delta p$ はゲート通過 $t$ 時間後における中心気圧と周辺気圧との 差 $(\mathrm{hpa}), a_{p}$ は 減衰率である。

減衰率については, ゲート通過後に中心気圧の変化が明確に現れる サイクロン, すなわちゲート付近通過時に $980 \mathrm{hpa}$ 以下の 4 つのサイ クロンを対象に分析した。グート通過後の気圧差の減衰率を図 9 に示 す。サイクロン毎にばらつきはあるが，1 サイクロン毎に平均值を求 め, さらに 4 つのサイクロンに対しての平均を求めたところ $a_{p}$ は $3.3 \%$ 程度となった。なお, $a_{p}$ の感度解析については注 2 に記した。

以上より得られた各種パラメータの統計量を表 3 にまとめる。
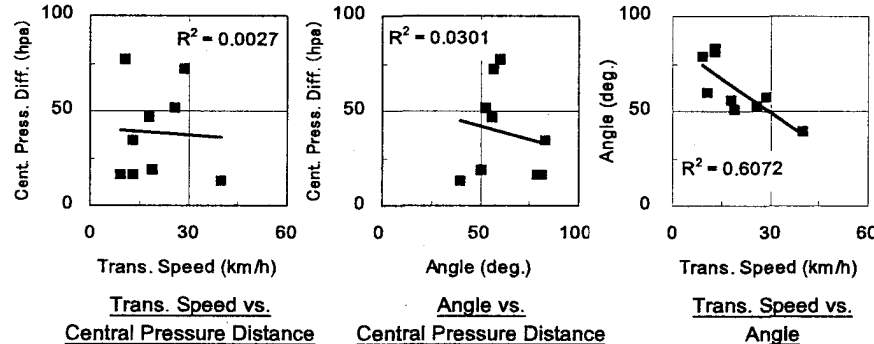

Central Pressure Distance Angle

図 8 パラメータ間の相関

表 2 最大旋衡風速半径と中心気圧

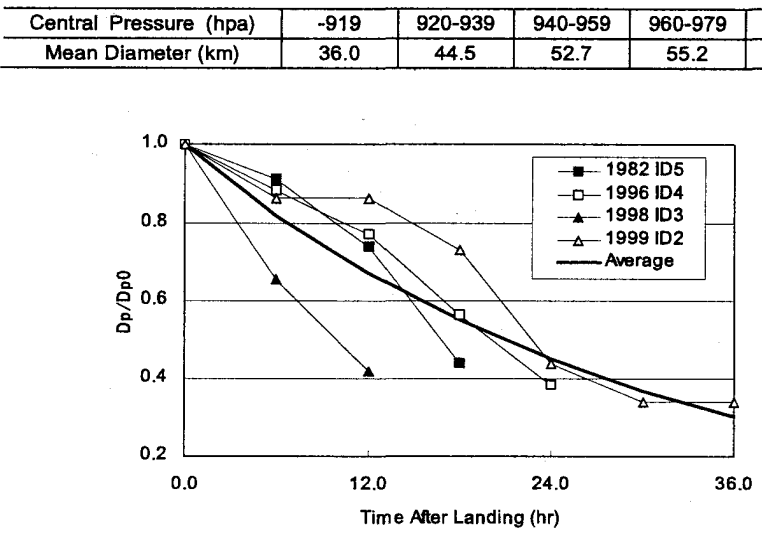

図 9 ゲート通過後の気圧差の変化

表 3 パラメータの特性

\begin{tabular}{c|c|c|c|c}
\hline Item & Unit & $\begin{array}{c}\text { Prob. } \\
\text { Distribution }\end{array}$ & Mean & Std. Dev. \\
\hline \hline Central Pressure Difference & $\mathrm{hpa}$ & Log-Normal & 31 & 0.7 \\
\hline Translational Speed & $\mathrm{km} / \mathrm{hr}$ & Log-Normal & 18 & 0.5 \\
\hline Passing Angle & $\mathrm{deg}$ & Normal & 62 & 15 \\
\hline Radius of the Maximum Wind Speed & $\mathrm{km}$ & Log-Normal & $36-52$ & 0.4 \\
\hline Frequency of Cyclone Passing & times/yr & Poisson & 0.26 & - \\
\hline Filling Rate Coefficient: $a_{p}$ & - & - & 0.033 & - \\
\hline
\end{tabular}




\section{4. 最大瞬間風速の算出}

得られた各種パラメータの統計量を用い, 仮定した確率密度分布を 基に設定ゲート上にてポアソン分布に従いモンテカルロシミュレー ションにより仮想的に 10000 年分のサイクロンを発生させ, 得られた サイクロン毎に対象地点での最大瞬間風速を推定する。

サイクロンのモデル化については, ハリケーンや台風において適用 される手法 9) と同様の手法を採用することとした。すなわち，気圧 分布を仮定し, 傾度風を求め, これを地上風に変換しガストファクタ 一を掛け合わせて算出する。シミュレートしたサイクロンのトラック 例を図 10 に示す。

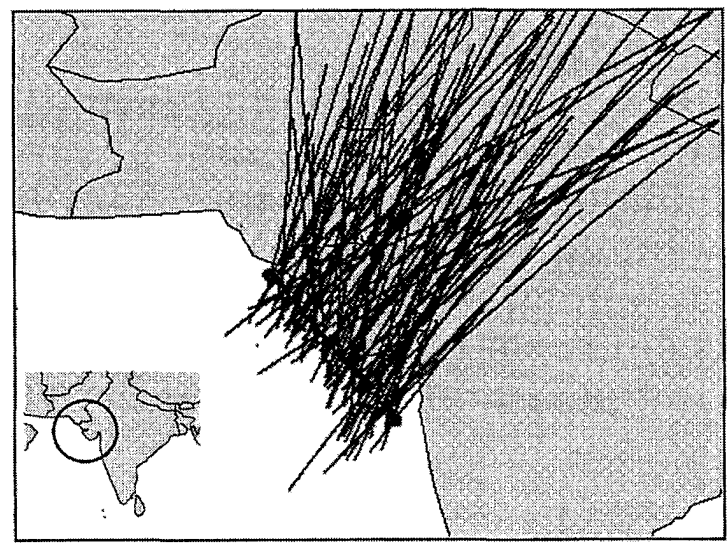

図 10 シミュレートしたサイクロン経路の例

\section{1 サイクロンの気压場}

発達したサイクロンの気圧場はその等圧線が同心円状になり, 中心 からの距離の関数として表され, Holland ${ }^{10)}$ はこの関数を以下のよう に与えた。

$$
P(r)=P_{C}+D_{P} \exp \left\{-\left(\frac{R_{m}}{r}\right)^{B}\right\}
$$

ここに, $P_{C}, D_{P}, R_{m}, r, B$ は, 台風の気圧場を表す変数で, そ れぞれ中心気圧 $(\mathrm{hpa})$, 中心気圧差 (hpa), 最大旋衡風速半径 $(\mathrm{km})$, サイクロン中心と対象地点との距離 $(\mathrm{km})$, 形状係数である。形状俰 数 $B$ は 1.0 2.5 が適切であるとし， $B=1$ の場合は Schloemer の提案 した同心円の式となる。Bの設定についてはサイクロン襲来時にお けるサイクロン周辺での気圧場の情報より設定する必要がある。 Holland は $B=1.5$ を推奨しているが, 低緯度のサイクロン程, 中心付 近における気圧勾配は高くなることから，ここでは, Tang et al. ${ }^{11)} に$ よる下式を用いることとした。

$$
B=1.5+\left(980-P_{C}\right) / 120
$$

\section{2 傾度風速の算出}

傾度風速の予測式は，気圧傾度力（気圧差により働く力）が遠心力 とコリオリカにバランスする運動方程式から求めた以下の式により 表される。これはブラトンの公式を用いて移動による流線曲率の変化 を考虑したものである。

$$
V_{\mathrm{gr}}=\frac{c \cdot \sin \theta-f r}{2}+\sqrt{\left(\frac{c \cdot \sin \theta-f r}{2}\right)^{2}+\frac{r}{\rho} \frac{\partial P(r)}{\partial r}}
$$

ここに, $V_{g r}$ は傾度風速 $(\mathrm{m} / \mathrm{s}), c$ は気圧場の移動速度 $(\mathrm{m} / \mathrm{s}), \quad r$ は サイクロン中心と対象地点との距離 $(\mathrm{m}), \theta$ はサイクロンの中心か ら対象地点人向かうベクトルを基準にサイクロンの進行方向を表す 角度 (反時計回りを正), $f$ はコリオリパラメータ $(1 / \mathrm{sec}), \rho$ は空 気密度 $\left(\mathrm{kg} / \mathrm{m}^{3}\right)$ を表す。

\section{3 傾度風から地表風への変換}

既往の研究にて傾度風から地表風への変換については様々な手法 が提案されている。藤井ら9によよれ゙, 台風 7705 および 7709 のデ 一タを基に，(6)式により傾度風から地表風一の变換を行っている。

$$
\frac{V_{s}}{V_{g r}}=G(\infty) \times\left[1+10^{0.0231 \Lambda_{p}-1.96}\left(\frac{\xi}{\xi_{p}}\right)^{m-1} \exp \left[\left(1-\frac{1}{m}\right)\left\{1-\left(\frac{\xi}{\xi_{p}}\right)\right\}^{m}\right]\right]
$$

ここに, $V_{s}$ は地表風, $V_{g r}$ は傾度風, $G(\infty)$ は周辺における $V_{s} / V_{g r}, \Delta p$ は対象地点における気圧差 $(\mathrm{hpa}), \xi$ は $r R_{m}$ との比率, $\xi_{p}$ と $m$ は 係数である。

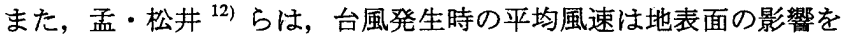
無視できる自由大気中の傾度風速 と淮定常的に発生する地表面の摩 擦による成分 の和として表すことができるとし，数值的に台風時の 大気境界層における強風を表す式を提案した。

$$
\begin{aligned}
& U(z)=v_{\theta \lambda}\left(\frac{z}{Z_{G}}\right)^{\alpha_{M}} \\
& \alpha_{M}=0.27+0.09 \log Z_{0}+0.018\left(\log Z_{0}\right)^{2}+0.0016\left(\log Z_{0}\right)^{3} \\
& Z_{G}=0.06 U_{G} / f_{\lambda}\left(\log R_{0 \lambda}\right)^{-1.45}
\end{aligned}
$$

ここに, $U(z)$ は高さ $z$ での風速 $(\mathrm{m} / \mathrm{s}), V_{\theta \lambda}$ は傾度風速 $(\mathrm{m} / \mathrm{s}), Z_{G}$ は傾度風の高さ $(\mathrm{m}), Z_{0}$ は粗度長 $(\mathrm{m}) ， f_{\lambda}$ は台風の持つ渦度と地 球の自転による渦度（コリオリ因子）の和である絶対渦度 $(1 / \mathrm{sec})$, $R_{0 \lambda}$ はロスビー数を表す。

その他, 山崎ら ${ }^{13)}$ は, 気象官署で得られた上空風と地表風の風向 別比を求め, シミュレーションで得られた傾度風に適用し地表風を求 めている。また, 勝地ら ${ }^{14)}$ は, 台風シミュレーションで得られた傾 度風について，一般的に適用されている保数，すなわち，海上におい ては $2 / 3$ を，地上においては $1 / 2$ を傾度風に掛け合わせている。

ここでは,インドにおける上空風と地上風との観測風速データが得 られないことから, 上記 3 手法, すなわち, 藤井らによる手法, 孟ら による手法および勝地らによる手法により地表風の評価を行ない比 較することとした。

なお，得られた地表風速に対して最大瞬間風速值を得るためには， ガストファクターを設定する必要がある。すなわち，

$$
U_{p}=G \cdot U(z)
$$

ここに, $U_{p}$ は最大瞬間風速 $(\mathrm{m} / \mathrm{s}), G$ はガストファクター,$U(z)$ は 高さ $z$ での 10 分間平均風速 $(\mathrm{m} / \mathrm{s})$ である。既往の研究 ${ }^{15)}$ にてハリ ケーン時と非ハリケーン時におけるガストファクターの違い,さらに は平均風速值に対するガストファクターのばらつき等が检討されて いる。ここでは, 既往研究に基づき, 表 4 に示した 1 時間平均風速に 対するガストファクターの Mean 值に Gust Factor Curve ${ }^{15)} よ り$ 読み取 った俰数（1.08）を適用し 10 分閒の平均值に対するガストファクタ 一注 ${ }^{3)}$ を求めた。 
表 4 設定したガストファクター

\begin{tabular}{c|c|c|c|c}
\hline \multirow{2}{*}{$\begin{array}{c}\text { Mean Wind } \\
\text { Speed }(\mathrm{m} / \mathrm{s})\end{array}$} & $\mathrm{N}$ & Mean & C.O.V. & Range \\
\cline { 2 - 5 } & 586 & 1.69 & 0.12 & $1.22-2.34$ \\
\hline \hline 10 & 546 & 1.63 & 0.11 & $1.29-2.75$ \\
\hline 15 & 279 & 1.58 & 0.09 & $1.27-2.02$ \\
\hline 20 & 71 & 1.59 & 0.07 & $1.33-1.89$ \\
\hline 25 & 23 & 1.57 & 0.07 & $1.40-1.81$ \\
\hline 30 & 7 & 1.56 & 0.05 & $1.44-1.70$ \\
\hline 35 & - & - & - & - \\
\hline 40 & - & - & - & - \\
\hline 45 & 1512 & 1.64 & 0.11 & $1.22-2.75$ \\
\hline All & & & &
\end{tabular}

\section{4 予想最大瞬間風速の検証}

モデルにより算出した最大瞬間風速值の妥当性を検証した。気象官 署における観測データが得られなかったので,インドの建築コードに おける Design Wind Speed ${ }^{16)}$ を基に作成された再現期間 200, 100, 50, 25 年における Peak Gust（3 秒間, Open Terrain, 高さ $10 \mathrm{~m}$ ) ${ }^{17}$ ) との比 較を行った。図 11 の Hazard Risk Zonation（以下 Hazard Map）は気象 官署の観測データに基づき作成されている。

まず，海岸沿いから内陸に従って約 $50 \mathrm{~km}$ 程度，離れた $\mathrm{A} \sim \mathrm{C}$ の 3 地点（緯度/経度は其々 $21.0^{\circ} / 70.0^{\circ}, 22.0^{\circ} / 71.0^{\circ}, 23.0^{\circ} / 72.0^{\circ}$ ）におい て 3 通りの地表風換算手法を用い $200,100,50,25$ 年再現期間の最 大瞬間風速を推定し, Hazard Map 上の最大瞬間風速值との比較を行 なった。その結果を図 12-14 に示す。海岸付近の A 地点については, いずれの再現期間においても Hazard Map の風速がモデルにより算出 した值よりも高くなっている。 $\mathrm{B}$ 地点については, A 地点まどの乘離 は見られず, 藤井らの手法によって算出された最大瞬間風速との乘離 は少ないことが判る。C 地点については, Hazard Mapの風速がいず れのモデルによる風速よりも低くなっている。藤井らのモデルでは， 他の 3 手法よりも計算される值は高くなるものの, Hazard Map との 比較において結果の適合性が高いことが判った。

また, 図 15 に藤井らによる地表風算出手法に基づいた 200 年再現 最大瞬間風速を示す。図中の数字は最大瞬間風速値を示す。ほぼ Hazard Map と同程度の風速分布になることが判る。これらの結果よ り藤井らによる手法に基づきリスク評価を行うこととした。

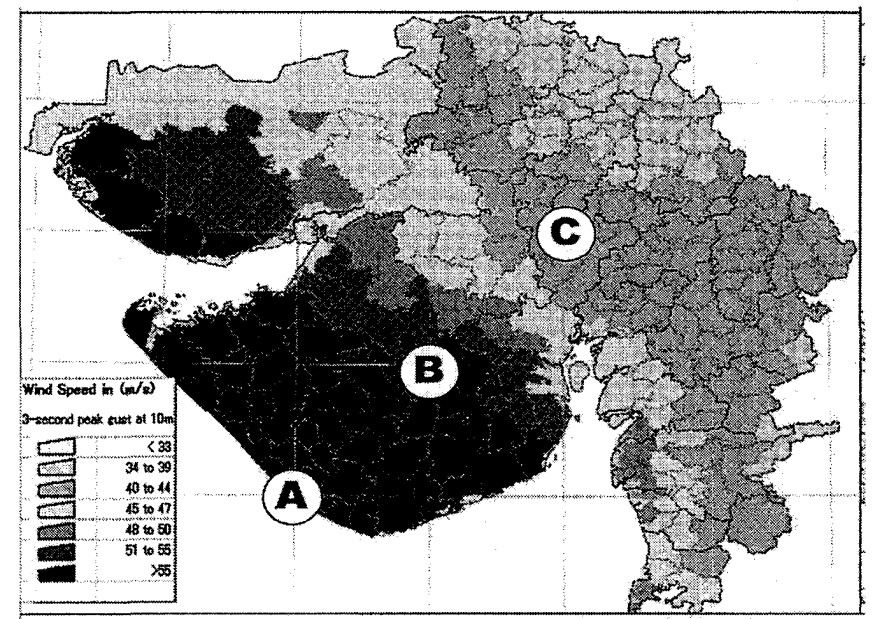

図 11 Hazard Risk Zonation（200 年再現期間）

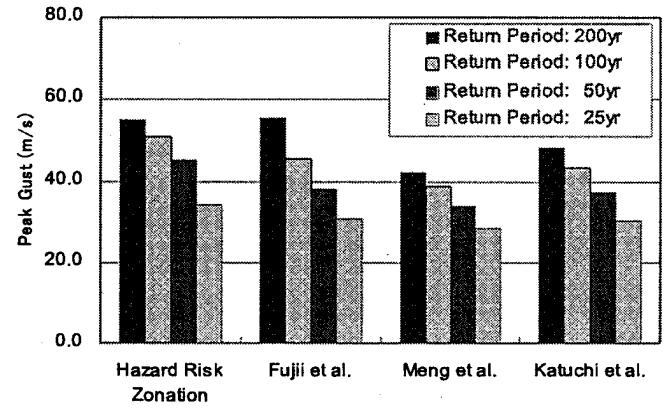

図 12 A 地点における最大瞬間風速値の比較

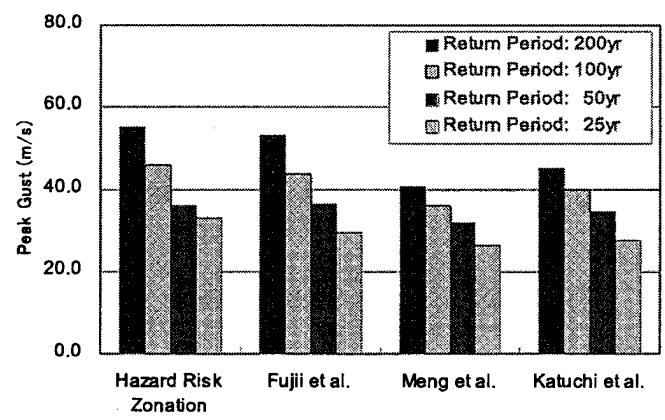

図 13 B 地点における最大瞬間風速値の比較

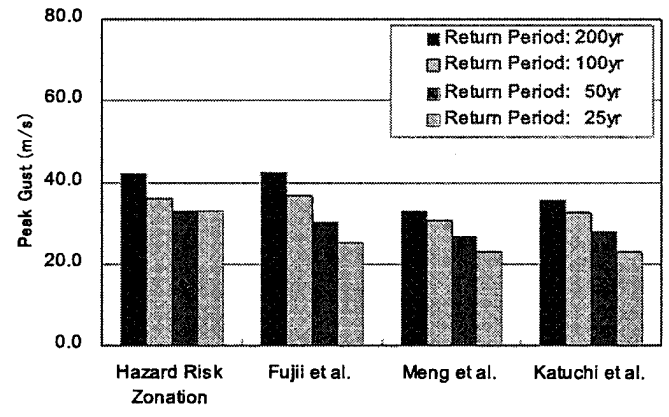

図 14 C 地点における最大瞬間風速値の比較

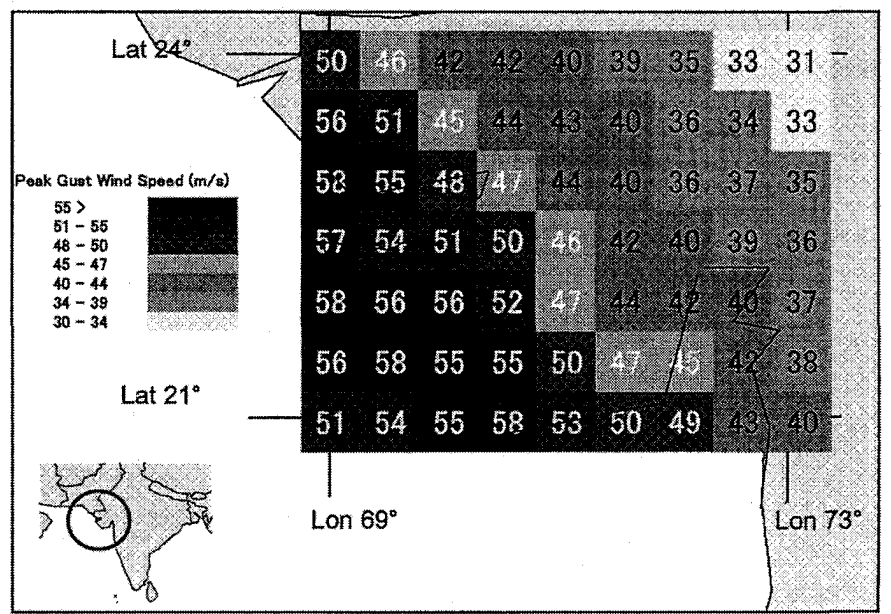

図 15 モデルによる最大瞬間風速（200 年再現期間） 


\section{5. リスク評価}

グジャラート周辺のサイクロンリスクを対象とした証券化のため には, 当該地域にリスク評価対象用にポートフォリオとして建物群を 仮定し，これらのリスク量を評価することとなる。証券化などのリス クファイナンスを行う上で, リスクカーブを用いたファイナンスの設 計が不可欠であることから, 本研究では, 過去のサイクロンデータを 基に得られた風災ハザードおよび評価対象物の脆弱性を示すバルナ ラビリティカーブを用いてポートフォリオのリスクカーブを作成す る。図16にリスク評価のフローを示す。

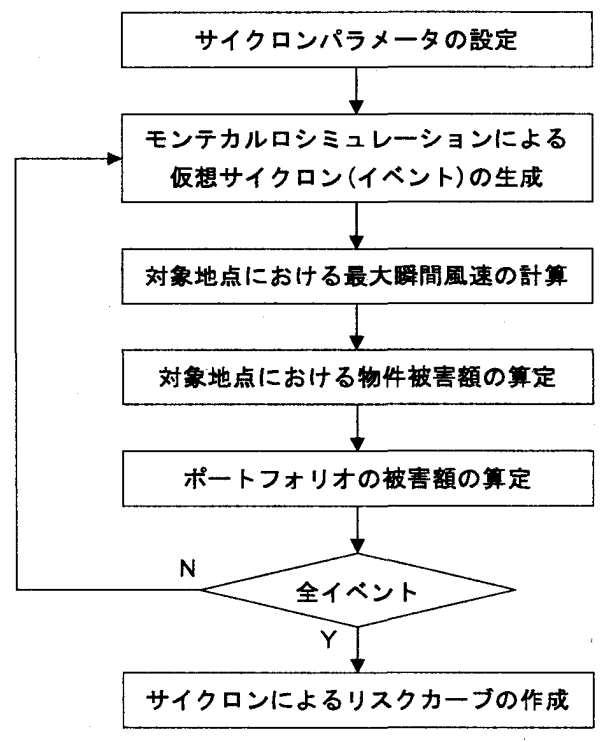

図 16 リスク評価のフロー

\section{1 バルナラビリティカーブの設定}

風災リスク量の評価には構造別バルナラビリティが必要となる。既 往研究によればオリッサ州を襲ったサイクロンによる被害データを 基に設定したもの ${ }^{18)}$ が知られているが Damage Ratio や風速值は不明 である。Arya らは既往の地震リスクの研究 ${ }^{19}$ に拈いて風災リスクに ついても言及している。

本研究では，このデータを参照して図 17 のようにデータをプロッ トし,プロット間を線形補間することによりバルナラビリティカーブ を設定した。なお，同図においては，「A3 Stone Wall Flat Roof 構造」 以外の構造物のバルナラビリティカーブは, 同一となっている。

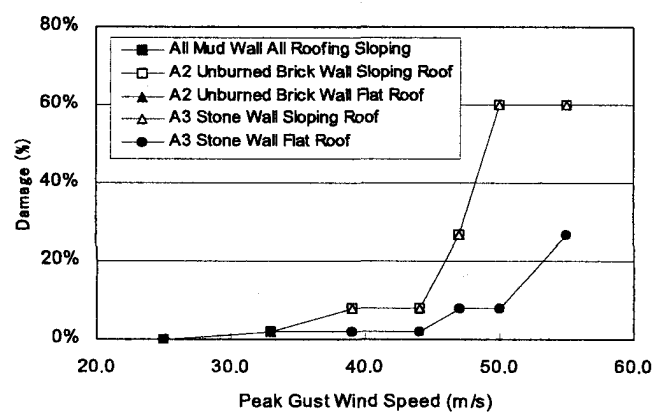

図 17 バルナラビリティカーブ

\section{2 リスクカーブの作成}

リスク評価に必要なポートフォリオを表 5 のように仮定した。すな
わち, 図 18 に示した 50 のロケーションに対してバルナラビリティカ 一ブの異なる $2 つ の$ 構造種別の建物を配置する。

図 19 に最大瞬間風速の比較を行った 3 地点 $\mathrm{A}, \mathrm{B}, \mathrm{C}$ における $\mathrm{A} 2$ タイプのバルナラビリティを適用した場合のリスクカーブを示す。地 点 $\mathrm{A}$ は海岸沿いに位置し，いずれの再現期間においても推定される 最大瞬間風速值は他 2 地点よりも大きく,リスク量も大きくなること が判る。なお，図 19 中の Expected Loss の 10,60にて不連続な点が見 られるが,これは設定したバルナラビリティカーブの特性が現れてい るためと考えられる。

次にポートフォリオ全体のリスクカーブを図 20 に示す。これは設 定したポートフォリオが同一のサイクロンにて同時に罹災するケー スも加味したリスクカーブとなっているが，同図中には，設定したポ 一トフォリオを構成する個々の物件ごとのリスクカーブを完全相関 の条件にて合算した場合，さらには無相関の条件にて合算した場合も 示した。完全相関の場合には，ポートフォリオ全体で評価した場合よ りもリスクを過大に評価し，無相関の場合には，リスクを過小に評価 してしまう可能性がある。すなわち，ポートフォリオに対するリスク を適切に評価するには, 個々の物件毎のリスクカーブの合算する方法 は不適切である。

表 5 設定したポートフォリオ

\begin{tabular}{c|c|c|c|c}
\hline $\begin{array}{c}\text { Type of } \\
\text { Vulnerability Curve }\end{array}$ & Structure & Value & $\begin{array}{c}\text { Number of } \\
\text { Bldg. }\end{array}$ & Total Value \\
\hline \hline A2 & $\begin{array}{c}\text { Unburned Brick Wall / } \\
\text { Sloping Roof }\end{array}$ & 100 & 50 & 5,000 \\
\hline A3 & $\begin{array}{c}\text { Stone Wall / } \\
\text { Flat Roof }\end{array}$ & 100 & 50 & 5,000 \\
\hline
\end{tabular}

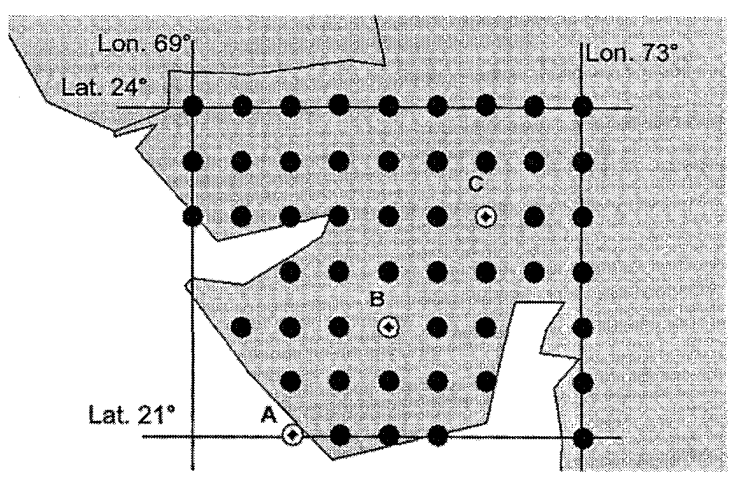

図 18 ポートフォリオを構成する建物群の配置

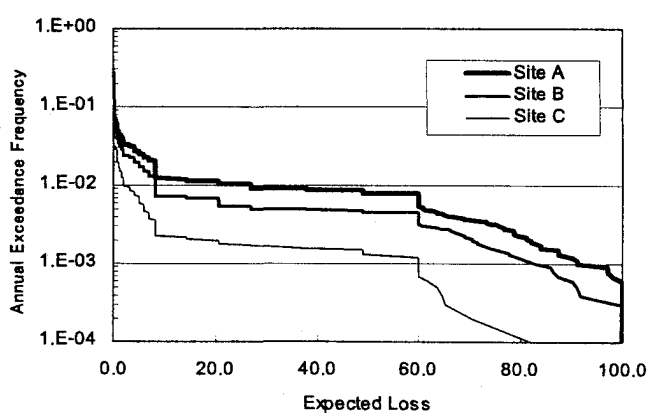

図 193 地点（A，B，C）におけるリスクカーブ 


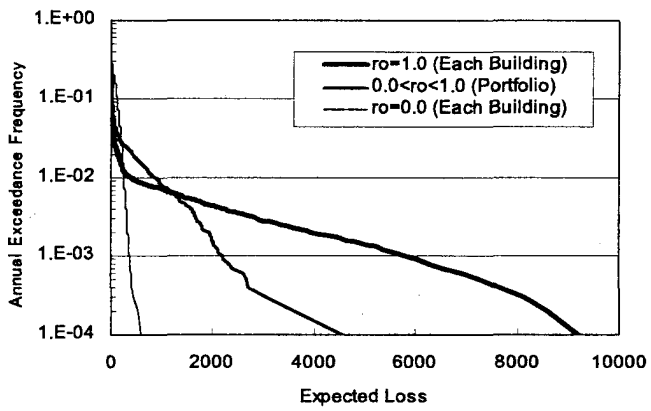

図 20 ポートフォリオのリスクカーブ

\section{6. まとめ}

本研究では, サイクロンリスクの証券化等のリスクファイナンスを 行う際の基礎的な研究を目的としてインド・グジャラート州に及ぼす サイクロンリスクを評価するために解析モデルの開発を行なった。そ の結果，以下の知見を得た。

(1) グジャラート周辺に萑来するサイクロンは低頻度事象であり， 風災リスク評価に必要な最大瞬間風速の統計データは得られ ないが，過去のサイクロンのパラメータを分析することで確 率論的な手法によりサイクロンによる風災リスクの評価手法 を構築することができる。

(2) 過去のサイクロンデータを分析し，中心気圧，進行速度等の サイクロンパラメータの統計的な性質を明らかにした。

(3) モデルで算出した最大瞬間風速とグジャラート州の風㷋ハザ 一ドマップにおける最大瞬間風速と比較したところ，モデル で算出した最大瞬間風速の適合度は高かった。

(4) グジャラート周辺に設定した架空のポートフォリオの風災リ スク量を算出したところ，サイクロンによる被害の相関を考 慮するか否かにより，リスクカーブの形状が大きく変わり， ポートフォリオ個々の物件を評価する場合にはサイクロンリ スクを過小もしくは過大に評価する可能性があることが明ら かとなった。

低頻度で甚大な被害をもたらすサイクロンについても,サイクロン 自体の統計的な性質を基にリスク評価を行うことができる。さら本結 果を基にサイクロンリスクヘッジのニーズに対応するために, リスク 証券化等のリスクファイナンスの設計も行うことができる。

今後は, 得られたリスク評価モデルに基づき中心気圧差や進行速度 等のサイクロンパラメータを用いたパラメトリックトリガーの設定 を行うこととしたい。

\section{謝辞}

中心気圧に関して貴重なご意見を頂いた Dr. Roger Flather，Dr. John A. Knaff (Colorado State Univ.) 並びに JTWC の Edward Fukuda 氏に謝 意を表します。

注1）パラメトリックトリガー：損害保険では，被害査定に基づき支払額を決 定するが，証券化によるリスクファイナンスを行う場合には，パラメト リックトリガーを設定し，客観的な指標を基に支払額を決める方法が知 られている。地歷の場合にはトリガーとして, 発生位置や規模等が用い られる。
注2）ゲート通過後の中心気圧の低下については, 過去の 4 つのサイクロンの 减衰率 $a_{p}$ の平均值 $(3.3 \%)$ を用いて評価を行っているため， $a_{p}$ のばらつ きは大きくなっている。ここでは, 4 つのサイクロンの $a_{p}$ の上限と下限 值，すなわち，サイクロン 1998 年 ID3，1999 年 ID2 について $a_{p}=5.4 \%$, $a_{p}=1.7 \%$ を用いて感度解析を実施した。図 A1 には再現期間 200 年, 減 衰率平均（3.3\%）を基準とした $\mathrm{A} \sim \mathrm{C}$ 地点での最大瞬間風速值比を示し ているが，海岸に近い A 地点ではサイクロンの減衰もなく，全ての減衰 率のケースにおいて変化は見られないが, 海岸から内陸になるに従い(B, C 地点）中心気圧の効果が計算結果に見られる。ただし，B 地点では $5 \%$ 程度，また C 地点では 10\%程度の差であり，特に設定したポートフォリ オの建物数は内陸になるにつれて減少することから最終的にリスク量へ 与える影響は小さいものと思われる。

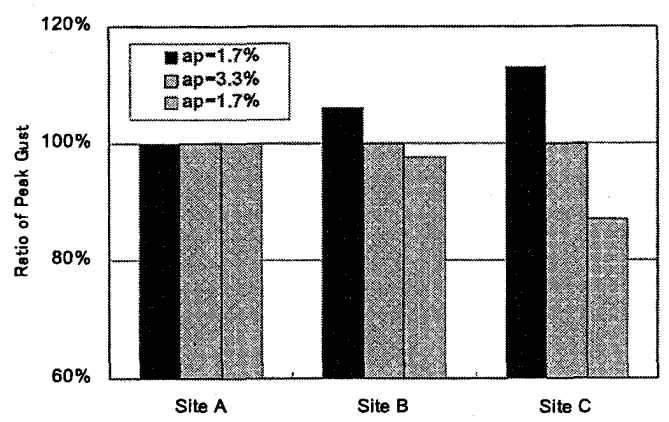

図 A1 サイクロン中心気圧の減衰率と最大瞬間風速

注3) 本シミュレーションで得られた地表風速は10分間の平均風速であるので， 表 4 より得られた 1 時閒平均風速に対するガストファクターを，10 分間 平均風速に対するガストファクターへ換算する必要がある。ここでは, 図A2 に示す既往の研究 ${ }^{15}$ による Gust Factor Curve から読み取った係数 1.08 程度で 1 時間平均風速に対するガストファクターの平均值を割り戻 し，10 分閒平均風速に対するガストファクターとしている。

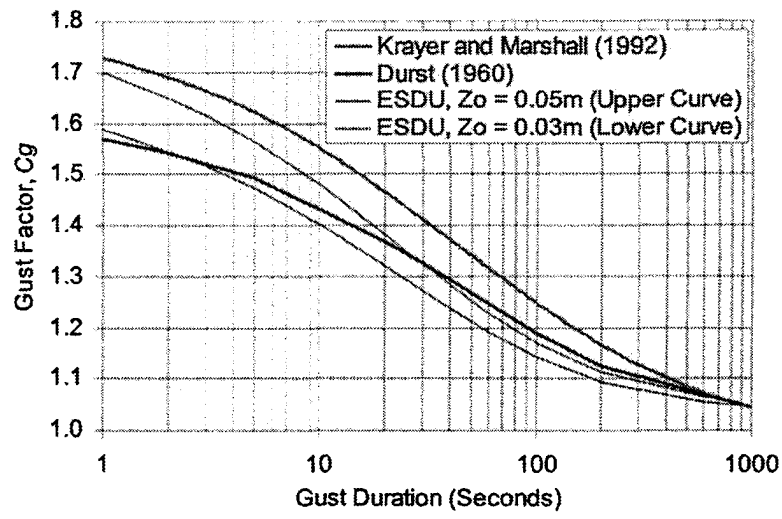

図 A2 Gust Factor Curve

\section{考文献}

1) 2004 Annual Cyclone Report, U.S. Naval Pacific Meteorology and Oceanography Center/ Joint Typhoon Warning Center, Pearl Harbor, Hawaii

2) 例えば, The Growing Appetite for Catastrophe Risk, The Catastrophe Bond Market at Year-End 2004, MMC Securities

3) Joint Typhoon Warning Center ATRC Archives, http://www.npmoc.navy.mil/jtwc

4) Hazarat Mir, Abdul Rashid, Waqarul Wheed Khan: Tropical Cyclone TC03A for the period $3^{\text {td }}$ June to $10^{\text {th }}$ June,1998, pp71-77,Vol2 Issue 4 (Nov,2005), Pakistan Journal of Meteorology

5) Atkinson, G.D., and Holiday: Tropical cyclone minimum sea level 
pressure-maximum sustained wind relationship for western North Pacific.Mon.Wea.Rev.,105, 421-427, 1977

6) Roger A. Flather: Storm Surge Prediction Model for the Northern Bay of Bengal with Application to the Cyclone Disaster in April 1991, pp172-190, Journal of Physical Oceanography, Vol.24, 1997.1

7) Bell, G.J.: Observations on the size of Typhoon eye, WMO technical conference on typhoon modification,nO.408, Manila,Oct.14-18,1974

8) Takeshi Fujii: Statistical Analysis of the Characteristics of Severe Typhoons Hitting the Japanese Main Islands, pp. 1091-1097, Monthly Weather Review, Vol. 126, Issue 4, 1998.4

9）藤井健，光田㲰：台風による強風の出現確率の予測について, 自然災害科 学, Vol.11, No.3, pp.125-144, 1992

10) G. Holland: An Analytic Model of the Wind and Pressure Profiles in Hurricanes, pp.1212-1218, Monthly Weather Review, Vol.108

11) Tang et al.: A Numerical Study of the Storm Surge Generated by Tropical Cyclone Jane, pp.963-976, Journal of Physical Oceanography, Volume 27, Issue $6,1997.6$
12）孟ほか：中立時の大気境界層における強風の鉛直分布特性，その 2 , 台風 時の強風, pp.3-14, Journal of Wind Engineering, No.86, 1996.1

13）山崎ほか: 送電用鉄塔の耐風設計のための風向別基本風速に関する検郡, pp.19-34, Journal of Wind Engineering, JAWE Vol.29, No.3, 2004.7

14）勝地ほか: 海面水温の影響を導入した台風シミュレーション, Journal of Wind Engineering, JAWE, Vol29, No.3(No.100), 2004.7

15) Vickery et al.: Hurricane Gust Factors Revisited, pp.825-832, Journal of Structural Engineering, 2005.5

16) Dr. Prem Krishina et al.: A Commentary on Indian Standard Code of Practice for Design Loads (other than earthquake) for Buildings and Structures Part 3 Wind Loads (Second Revision)

17) Gujarat State Disaster Management Authority: Gujarat Cyclone Hazard Risk Zonation 200-year return period, MAP No.: CYM-07 of 08, Date 18/8/2006

18) Document of World Bank: India Financing Rapid Onset Natural Disaster Losses in India -A Risk Management Approach, Report No.26844-IN MS, 2003.8

19) Anand S. Arya: Recent developments toward earthquake risk reduction in India, pp1270-1277, Current Science, Vol.79, No.9, 2000.10 